\title{
DUKUNGAN PEMERINTAH DALAM MENCEGAH PENYALAHGUNAAN NARKOBA DI KOTA SURABAYA
}

\author{
Nuri Pina, Oedojo Soedirham \\ Departemen Promosi Kesehatan dan Ilmu Perilaku \\ Fakultas Kesehatan Masyarakat Universitas Airlangga \\ Email: rifi_f@yahoo.com
}

\begin{abstract}
Drugs are a serious problem that need to be solved together. Based on the data from City Narcotics Agency (BNNK) the number of drug abusers in Surabaya is increased. The city of Surabaya has issued local law (Perwali) Number 65 of 2014 about policies and strategies for the area in the field of prevention, Combating Drug Abuse and Illicit Drugs (P4GN). The regulation has been in accordance with the healthy public policy. The aim of this study is to determine the government's support in preventing drug abuse. The special purpose is to determine the achievement of the target, implementation constraints, prevention, and the responsiveness of the community. The research methods was qualitative approach. Collecting the data through in-depth interviews, documentation, and observation. Informants from SKPD that is related to the prevention of drug abusers, employee from BNN Surabaya, and a third resident of drug abusers in Surabaya had selected by purposive sampling. The results in phase to the target is not in accordance with the Perwali, because it still has obstacles ie outreach to street children, and the commitment in activities. The government's efforts in implementing prevention programs of drug abusers were in conformity with Perwali, including socialization, curriculum integration on antidrug, TOT, the establishment of peer counselor, and the establishment of the youth anti-drug cadre. Responsiveness of people have started going well. People have the awareness and courage to report drug abuse related to BNN city of Surabaya to be rehabilitated.
\end{abstract}

Keywords: government suport, drug prevention, Surabaya

\begin{abstract}
Abstrak: Narkoba merupakan masalah yang serius untuk diselesaikan bersama. Berdasarkan data Badan Narkotika Kota (BNNK) Surabaya, jumlah penyalahguna narkoba di Surabaya meningkat di Tahun 2014 dan 2015. Pemerintah kota Surabaya sudah mengeluarkan Perwali Nomor 65 Tahun 2014 tentang kebijakan dan strategi daerah bidang Pencegahan, Pemberantasan Penyalahgunaan dan Peredaran Gelap Narkoba (P4GN). Peraturan tersebut sudah sesuai dengan kebijakan publik berwawasan kesehatan. Tujuan penelitian ini untuk mengetahui dukungan pemerintah dalam mencegah penyalahgunaan narkoba. Tujuan khusus mengetahui pencapaian target sasaran, kendala pelaksanaan, usaha pencegahan, dan responsifitas masyarakat. Metode penelitian menggunakan pendekatan kualitatif. Pengumpulan datanya melalui wawancara mendalam, dokumentasi, dan observasi. Informan dipilih secara purposive sampling yaitu SKPD terkait pencegahan penyalahguna narkoba, pegawai BNN Kota Surabaya, dan 3 residen penyalahgunaan narkoba di Surabaya. Hasil penelitian pada pencapaian target sasaran belum sesuai dengan Perwali tersebut, karena masih memiliki kendala yaitu penjangkauan terhadap anak jalanan, dan komitmen dalam kegiatan. Usaha pemerintah dalam melaksanakan program pencegahan penyalahguna narkoba sudah sesuai dengan Perwali, diantaranya sosialisasi, kurikulum integrasi anti narkoba, TOT, pembentukan konselor sebaya, dan pembentukan kader pemuda anti narkoba. Responsifitas masyarakat sudah mulai berjalan dengan baik. Masyarakat memiliki kesadaran dan keberanian untuk melaporkan terkait penyalahgunaan narkoba ke BNN kota Surabaya untuk dilakukan rehabilitasi.
\end{abstract}

Kata kunci: dukungan pemerintah, pencegahan narkoba, Surabaya

\section{PENDAHULUAN}

Narkoba merupakan masalah yang perlu diperhatikan oleh semua elemen masyarakat. Berdasarkan data dari Badan Narkotika Nasional, kasus penyalahgunaan narkoba setiap tahunnya meningkat. Kasus tertinggi adalah golongan narkotika. Tahun
2008 berjumlah 10.008 jiwa. Tahun 2009 meningkat menjadi 11.140 jiwa. Tahun 2010 meningkat menjadi 17.898 jiwa. Tahun 2011 meningkat menjadi 19.128 jiwa. Tahun 2012 menurun menjadi19.081 jiwa. Berdasarkan latar belakang pendidikan, terbanyak pengguna berlatar belakang SMA 
yaitu 19.730 jiwa, diikuti SMP yaitu 9.768 jiwa. Latar belakang yang paling banyak dari korban penyalahgunaan narkoba adalah tingkat SMA dan remaja (KemenkesRI, 2014).

Jawa Timur merupakan provinsi padat penduduk, dengan jumlah 37.070.731 juta jiwa, serta luas wilayah $47.922 \mathrm{~km} 2$. Informasi dari Badan Narkotika Nasional (BNN) tahun 2013, penyalahguna narkoba di Jawa Timur memiliki peringkat nomor dua setelah Jakarta. Menurut Ditjen Pemasyarakatan, jumlah narapidana terkait masalah narkoba 49.896 jiwa, terdiri dari produsen sekitar 952 jiwa, bandar 5.430 jiwa, pengedar berjumlah 22.092 jiwa, penadah 2.490 jiwa dan pengguna 18.905 jiwa. Semakin tinggi penyalahguna narkoba di jawa timur sehingga dikeluarkan kebijakan yaitu Pergub Nomor 74 Tahun 2012 (KemenkesRI, 2014).

Berdasarkan data BNNK Surabaya, kasus penyalahguna narkoba masih meningkat. Hal ini terhitung mulai tahun 2014 berjumlah 403 jiwa dengan jumlah laki-laki 376 jiwa dan perempuan 27 jiwa. Tahun 2015 meningkat menjadi 423 jiwa dengan jumlah laki-laki 248 jiwa dan perempuan 42 jiwa. Peningkatan angka penyalahguna narkoba tersebut menjadi masalah bersama bagi masyarakat Surabaya. Informasi dari Badan Narkotika kota Surabaya, penyalahgunaan narkoba disebabkan oleh kurangnya pemahaman tentang agama dan keinginan untuk sekedar mencoba.

Berdasarkan hasil dari kegiatan rutinitas meeting bersama residen di salah satu tempat rehabilitasi sosial kota Surabaya mengatakan bahwa faktor utama penyebab dari penyalahgunaan narkoba yaitu pergaulan dan lingkungan.

Narkoba memiliki efek buruk baik secara individu, keluarga, maupun masyarakat. Efek yang terjadi terhadap individu diantaranya gangguan mental, ketergantungan, gangguan kesehatan, menjadi pelaku kejahatan, menghancurkan masa depan sendiri serta mengakibatkan kematian. Efek buruk terhadap keluarga yaitu gangguan keharmonisan, aib, serta dapat menghilangkan harapan dari keluarga. Akibat yang ditimbulkan terhadap masyarakat pada penyalahgunaan narkoba yaitu mengganggu ketertiban, rasa takut serta meresahkan lingkungan sekitar. Akibat penyalahgunaan narkoba yang ditimbulkan terhadap bangsa dan negara yaitu merugikan harkat dan martabat bangsa, merusak generasi muda serta merusak ketahanan nasional (Bakhri, 2012). Penyalahgunaan narkoba jika tidak ditangani secara serius sejak dini, dikhawatirkan merusak masa depan generasi penerus bangsa. Maka dari itu, perlu upaya yang dilakukan secara terusmenerus demi mengontrol dan mencegah peredaran gelap narkoba untuk Indonesia bisa terlepas dari bahaya narkoba tersebut.

Peraturan Walikota Surabaya Nomor 65 Tahun 2014 merupakan turunan dari Intruksi Presiden Nomor 12 Tahun 2011 tentang pelaksanaan kebijakan dan strategi nasional bidang P4GN. Tujuan P4GN adalah menurunkan jumlah penyalahguna narkoba. Adanya kebijakan Perwali tersebut mampu menurunkan jumlah penyalahguna narkoba di Surabaya sesuai dengan tujuan Perwali yaitu Surabaya bebas dari narkoba dan tidak ada penyalahguna narkoba yang baru.

Menurut WHO (2009), promosi kesehatan merupakan proses peningkatan kontrol dalam kesehatan. Menurut ilmu kesehatan masyarakat, promosi kesehatan memiliki arti sebagai bagian dari pencegahan masalah kesehatan. Salah satunya yang berkaitan dengan pencegahan masalah kesehatan adalah program pencegahan penyalahguna narkoba pada Perwali Surabaya nomor 65 tahun 2015. Berdasarkan strategi promosi kesehatan sesuai deklarasi Ottawa Charterada lima diantaranya kebijakan publik berwawasan kesehatan, lingkungan yang mendukung terhadap kesehatan, peningkatan partisipasi masyarakat, pengembangan keterampilan terhadap anggota masyarakat, reorientasi pelayanan kesehatan (Notoatmodjo, 2012).

Strategi kebijakan publik yang berwawasan kesehatan adalah kebijakan yang selalu menyertakan kesehatan dalam semua aspek. Tujuan kebijakan yaitu menciptakan lingkungan yang mendukung seseorang agar melakukan hidup sehat. Selain itu lingkungan memiliki peranan penting dalam perlindungan terhadap bahaya narkoba. Lingkungan yang dimaksud 
meliputi tempat tinggal, tempat bekerja, komunitas lokal, fasilitas umum termasuk akses dan sumber daya kesehatan, serta peluang untuk pemberdayaan (Notoatmodjo, 2012).

Notoatmodjo (2012), mengatakan partisipasi masyarakat memiliki peranan penting dalam pencegahan masalah kesehatan yaitu penyalahgunaan narkoba. Partisipasi tersebut bisa berupa pemberian informasi mengenai bahaya narkoba, pelaporan kasus narkoba, sebagai kader pemuda anti narkoba, dan konselor sebaya. Setiap masyarakat diharapkan mampu mengendalikan hidupnya serta merubah perilakunya yang negatif. Hal ini dilakukan dengan cara berfikir kreatif kritis, empati yang tinggi, kemampuan komunikasi yang baik, kepercayaan diri kuat, pengendalian emosi yang baik, serta mampu mengatasi tekanan lingkungan sekitar. Cara ini dilakukan pada suatu organisasi pelayanan kesehatan dengan melibatkan para profesional kesehatan, instansi pelayanan kesehatan, dan pihak pemerintah terkait (Notoatmodjo, 2012).

Stahl et al (2006) mengatakan beberapa pengembangan pada Health In All Policies (HIAP) yaitu usaha untuk meningkatkan derajat kesehatan serta memberikan kontribusi kepada kesejahteraan dan kekayaan bangsa. Kontribusi tersebut melalui struktur, mekanisme dan tindakan yang direncanakan serta dikelola oleh sektor selain kesehatan.

Pelaksanaan program pencegahan penyalahguna narkoba tidak berdiri sendiri, akan tetapi kerjasama antar SKPD yaitu Dinas Pendidikan, Dinas Kebudayaan dan Pariwisata, Dinas Pemuda dan Olahraga, Dinas Kesehatan, dan BNN kota Surabaya. Pelaksanaan program pencegahan penyalahguna narkoba sesuai dengan salah satu strategi HIAP yaitu melakukan mitra antar sektoral (Stahl, 2006). Kesehatan penduduk tidak hanya produk dari kegiatan sektor kesehatan saja, akan tetapi melibatkan beberapa sektor dan ditentukan oleh kondisi hidup serta faktor lain yaitu faktor ekonomi dan sosial (Stahl, 2006).

BNN memiliki peranan dalam menjalankan tugas pokok dan fungsi pada P4GN terkait pencegahan dan pemberantasan narkoba. BNN juga memiliki arah kebijakan sebagai berikut: peningkatan sumber daya alam, pencegahan, sosialisasi, koordinasi, kerja sama internasional, peran serta dari semua elemen masyarakat baik kalangan atas ataupun bawah, penegakan hukum, rehabilitasi, komunikasi, informasi dan edukasi, pengawasan dan pengendalian (BNN, 2009).

Berdasarkan Peraturan Walikota Surabaya nomor 65 tahun 2014 tentang rencana aksi kebijakan dan strategi daerah bidang P4GN, Perwali yang berkaitan dengan bidang pencegahan penyalahguna narkoba yaitu,

"Sosialisasi bahaya narkoba, membuat modul, pembentukan tim sebaya, memberikan pelatihan dan aktivitas leadership untuk mencegah penggunaan narkoba, membentuk tim deteksi dini, membentuk kader pendamping terhadap para pengguna narkoba, memberi informasi dan edukasi tentang bahaya penyalahgunaan narkoba, membentuk kader anti narkoba".

Pemerintah kota Surabaya memiliki dukungan penting dalam hal pencegahan penyalahguna narkoba. Pemerintah melaksanakan program sesuai dengan Perwali.

BNN telah menetapkan lingkungan pendidikan sebagai salah satu sasaran strategis pencegahan penyalahguna narkoba. BNN juga sebagai focal point dalam pencegahan penyalahgunaan narkoba. BNN melalui paradigma baru berperan lebih humanis dalam menangani penyalahgunaan dan korban penyalahgunaan narkoba. BNN juga sebagai rujukan dalam pencegahan penyalahgunaan narkoba. Implemetasi kebijakan berupa pemberian informasi didukung penuh partisipasi sekolah, keluarga, dan masyarakat (BNN, 2009).

Sistem kebijakan merupakan beberapa pola institusional yang terdiri dari tiga elemen penting yaitu: lingkungan kebijakan, pelaku kebijakan, dan kebijakan publik (Dunn, 2012). Kebijakan publik memiliki pengaruh yang kuat dalam perubahan terhadap masalah kesehatan yaitu berupa Perwali Surabaya Nomor 65 Tahun 
2014. Adanya kebijakan tersebut mampu menurunkan jumlah penyalahguna narkoba di kota Surabaya. Tujuan penelitian ini yaitu untuk mengetahui dukungan pemerintah kota Surabaya dalam hal pencegahan penyalahguna narkoba tersebut.

\section{METODE}

Penelitian ini merupakan penelitian kualitatif. Pengumpulan data menggunakan teknik wawancara mendalam, observasi, dan studi dokumentasi. Informan yang dipilih secara purposive sampling, dengan jumlah informan 8 orang. Informan terdiri kepala seksi pendidikan masyarakat bidang Pendidikan Luar Sekolah (PLS) Dinas Pendidikan, kepala seksi Pengendalian dan Pemberantasan Penyakit (PPP) bidang Pengendalian dan Pemberantasan Masalah Kesehatan (P2MK) Dinas Kesehatan, kepala seksi kepemudaan Dinas Pemuda dan Olahraga, Staff bidang rekreasi hiburan umum (RHU) Dinas Pariwisata dan Kebudayaan, kepala Seksi Pencegahan dan Pemberdayaan Masyarakat BNN Kota Surabaya, masing-masing sebanyak 1 informan dan 3 residen penyalahguna narkoba di kota Surabaya. Alasan SKPD tersebut terpilih sebagai informan karena sesuai dengan surat keputusan Walikota Surabaya nomor 188.45/260/436.1.2/2013 Tanggal 1 Juli 2013 Tentang Tim aksi P4GN. Penelitian ini berlangsung antara bulan November 2015 sampai Januari 2016. Lokasi penelitian yaitu Dinas Pendidikan yang bertempat di Jl. Jagir Wonokromo No. 356 Surabaya, Dinas Pemuda dan olahraga yang bertempat di Jl. Jimerto 25-27 Lt. IV Surabaya, Dinas kesehatan bertempat di Jl. Jemursari No. 197 Surabaya, Dinas Kebudayaan dan Pariwisata yang bertempat di Jl. Adityawarman 110 Surabaya, BNN Kota Surabaya di Jl. Gayungsari Barat III 47/49 Surabaya, dan para residen di RSOS Jl. Pandugo YKP 30 PC Surabaya.

Data pemerintah tentang dukungan pemerintah kota Surabaya dalam upaya pencegahan penyalahguna narkoba dan alasan residen menyalahgunakan narkoba. Data ini diperoleh dari hasil wawancara mendalam. Data sekunder diperoleh dari studi dokumentasi tentang jumlah penyalahguna narkoba di kota Surabaya, program pencegahan narkoba serta observasi tentang kegiatan pencegahan penyalahgunaan narkoba. Instrumen yang digunakan adalah peneliti sendiri, panduan wawancara, perekam suara, kamera dan lembar observasi. Analisis data dilakukan dengan transkip dari wawancara, observasi, dan studi dokumentasi. Kemudian dilakukan penyederhanaan dengan merangkum. Selanjutnya data disusun berdasarkan klasifikasi dan diteliti kembali dengan cermat. Setelah data dianggap cukup dan telah sesuai maka laporan disusun sampai pada kesimpulan.

\section{HASIL}

Hasil penelitian menunjukkan peran Pemerintah sudah sesuai dengan Perwali. Peran tersebut diantaranya sosialisasi, pembentukan koselor sebaya, pembentukan kader pemuda anti narkoba, kurikulum integrasi anti narkoba, dan pelaksanaan Traininf of Trainer (TOT).

Dari hasil penelitian didapatkan perbandingan antara normatif dengan realita kegiatan yang dilakukan oleh Pemerintah kota Surabaya yang disajikan pada tabel 1 .

Berdasarkan tabel 1, Pemerintah kota Surabaya memberikan dukungan penuh dalam pencegahan penyalahguna narkoba. Dukungan ini seperti sosialisasi, pembentukan konselor sebaya, kader pemuda anti narkoba, pelaksanaan TOT, dan kurikulum integrasi anti narkoba. pelaksanaan program memiliki capaian target sasaran yaitu SMA, SMP, masyarakat, karang taruna, PNS, dan ibu rumah tangga. Pencapaian target sasaran belum memiliki kesesuaian dengan standart normatif, karena memiliki beberapa kendala di lapangan antara lain kesulitan melakukan penjangkauan terhadap anak jalanan, SDM yang terbatas, dan belum dilaksanakan pemantauan setelah program dibentuk.

Berdasarkan hasil wawancara dengan infoman di BNNK Surabaya, BNNK melaksanakan program pencegahan penyalahguana narkoba masih belum sesuai dengan target sasaran. Berikut ungkapannya, 
Tabel 1. Standar target dan temuan di lapangan

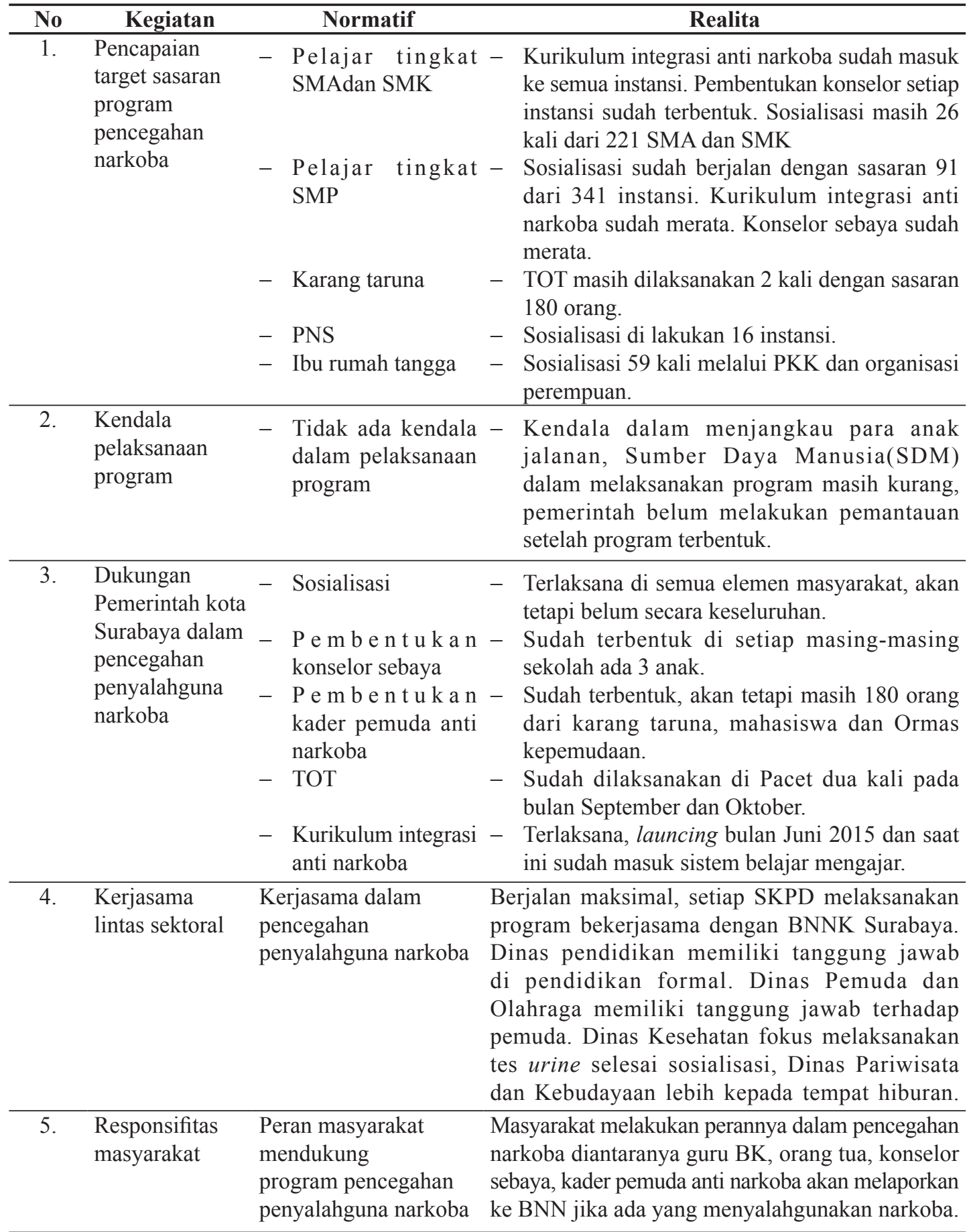

“...Luasnya kota surabaya dan juga padatnya penduduk kota surabaya, banyak sekali sekolah yg belum kita jangkau, sedangkan anggaran dari pemerintah itu terbatas, jadi pelaksanaan kami dalam menjangkau kami memerikan informasi dari mulut ke mulut, terus juga mengadvokasi guru dan wali murid..." $(\mathrm{I} 5,27)$
Kemudian pihak BNNK Surabaya mengatakan pelaksanaan sosialisasi sering kepada pendidikan formal.

“...Sosialisasi kita sering ke tempat Sekolah-sekolah mbak ya, di SD, SMP, SMK, SMA, tapi kita juga ke masyarakat...”.(I5,27) 


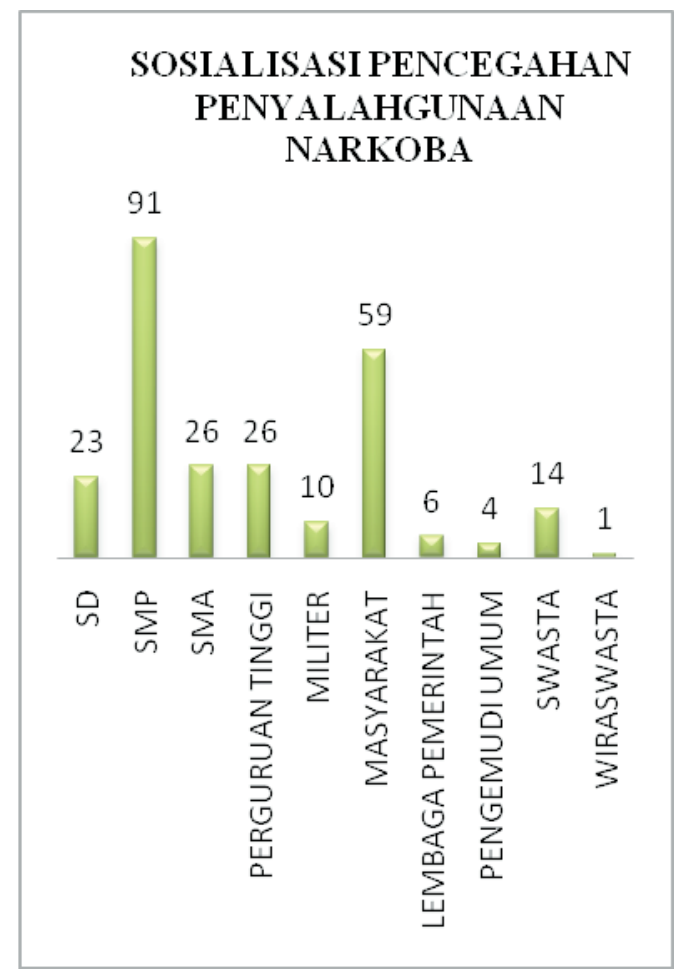

Gambar 1. Kegiatan sosialisasi pencegahan penyalahguna narkoba di kota Surabaya

Sesuai informasi BNNK Surabaya, program pencegahan penyalahguna narkoba belum mencapai target sasaran secara keseluruhan. Hal ini dikarenakan ketidak seimbangan antara sasaran dengan pelaksana program. Berdasarkan hasil studi dokumentasi, pemerintah mencapai target sasaran program sosialisasi belum semua masyarakat tercakup.

Berdasarkan gambar 1, Pemerintah melaksanakan sosialisasi terbanyak di SMP sebanyak 91 instansi dari 341 instansi. Pelaksanaan sosialisasi belum memiliki kesesuaian dengan jumlah instansi sasaran. Dinas Pendidikan juga mengungkapkan pencapaian target sasaran program dan usaha pencegahan. Sesuai dengan kutipan berikut ini,

“...Jadi kemaren dinas pendidikan itu bersama BNN, launcing kurikulum integrasi anti narkoba di sekolah SMP SMA mbak, jadi misalnya matematika atau pelajaran bahasa di indonesia, dijelaskan bagaimana narkoba itu, seperti apa, dan macem macem seperti itu...." $(\mathrm{I} 1,34)$
Berdasarkan ungkapan informan I1, pemerintah sudah mengeluarkan kurikulum integrasi anti narkoba dan masuk dalam sistem belajar mengajar di sekolah tingkat SMP, SMA. Kurikulum integrasi anti narkoba menjelaskan tentang pemahaman narkoba, dan pencegahannya. Dinas Pendidikan tidak hanya launcing kurikulum, akan tetapi sosialisasi terkait pemahaman narkoba seperti kutipan berikut ini,

“...Kalau Dinas Pendidikan terkait sosialisasi, terutama ke sekolah dan mahasiswa, selain itu juga ada pelatihan konseling guru TK, jadi anaknya, Guru BK, orang tuanya, dan kepala sekolah, kalau ini nggak sinkron, enggak sambung, percuma mbak..." $\left(\mathrm{I}_{1}, 34\right)$

Dinas Pendidikan dalam melakukan pencapaian target sasaran sosialisasi yaitu kalangan siswa dan mahasiswa, selain itu Dinas Pendidikan melakukan pelatihan kepada para guru BK, orang tua murid, dan kepala sekolah. Sama halnya dengan yang diungkapkan oleh Dinas Pemuda dan Olahraga. Sesuai dengan kutipan ini,

“...Jadi kita kan karena di Dispora itu kan ada bidang pemuda jadi tujuan kita untuk pencegahan penyalahguna narkoba itu adalah pemuda, sesuai dengan Undang-Undang kepemudaan Nomor 40 Tahun 2009, itu usia pemuda adalah dari 16-30, itu yang kita tuju..."'(I2,52)

Kemudian Dinas Pemuda dan Olahraga juga mengatakan pencapaian sasaran sosialisasi selama tahun 2015. Sesuai dengan kutipan berikut ini,

“...Kita sosialisasi dalam satu tahun itu ada 31 kali kegiatan per kecamatan, sistemnya perkecamatan kita roudshow mbak...."(I 2,52$)$

Dinas Pemuda dan Olahraga mengatakan terkait sasaran dalam pelaksanaan program. Sesuai kutipan berikut ini, 
“...Bisa anak karangtaruna, bisa anak sekolah, bisa anak mahasiswa juga, pemuda lainnya pokoknya yang orang umur itu tadi 16-30 tahun... "(I2,52)

Selanjutnya Dinas Pemuda dan Olahraga mengungkapkan pelaksanaan TOT dan sampai pembentukan kader pemuda anti narkoba. Seperti kutipan berikut ini,

“...Kita melakukan TOT 2 kali, TOT baru tahun ini pelaksanaanya ditrawas tempatnya mbak selama 3 hari, kita latih mereka, kita latih dari segi fisik, dari segi mentalnya..." $(\mathrm{I} 2,52)$

Berdasarkan informasi Dinas Pemuda dan Olahraga (Dispora), mereka sudah melaksanakan sosialisasi 31 kali selama tahun 2015, dan TOT selama 3 hari bertempat di Trawas Mojokerto. Peserta TOT diharapkan bisa fokus sehingga mampu melahirkan kader pemuda anti narkoba yang berkualitas. Berbeda dengan Dinas Pariwisata dan Kebudayaan, mereka mengungkapkan sasaran fokus terhadap tempat hiburan. Sesuai dengan kutipan berikut ini,

“...Kita sasarannya fokus di tempat tempat hiburan mbak ya, dan apabila mereka membuka usaha yang berhubungan dengan narkoba gitu, harus memenuhi syarat ketentuan. Jika melanggar akan kita berikan sanksi secara administratif dengan mencopot izin... "' $(\mathrm{I} 3,35)$

Dinas Pariwisata dan Kebudayaan juga mengungkapkan sasaran dalam pelaksanaan sosialisasi. Berikut kutipannya,

“...Kita juga pernah melakukan sosialisasi di tempat hiburan dengan kerjasama BNN dan Dinas Kesehatan..." $(\mathrm{I} 3,35)$

Dinas Pariwisata dan Kebudayaan mengungkapkan pencapaian target sasaran di beberapa tempat hiburan. Mereka memberikan ketentuan dan syarat secara administratif pada awal proses perizinan membangun tempat hiburan. Dinas
Pariwisata dan Kebudayaan juga sudah melakukan sosialisasi ke beberapa tempat hiburan, tetapi belum semuanya.

Berdasarkan informasi beberapa Dinas, mereka belum mencapai target sasaran secara keseluruhan, hanya kurikulum integrasi anti narkoba dan konselor sebaya. Akan tetapi pemerintah sudah melaksanakan program sesuai Perwali yaitu sosialisasi, pembentukan kader pemuda anti narkoba, pembentukan konselor sebaya, pelaksanaan TOT, dan kurikulum integrasi anti narkoba.

Kendala pemerintah dalam mencapai sasaran yaitu sulit dalam menjangkau kalangan anak jalanan, keterbatasan SDM, belum dilakukan pemantauan. Sesuai kutipan berikut ini,

“...Kita kesulitan kalau sosialisasi ke anak-anak jalanan mbak ya, karena disana ada kayak mafia nya gitu mbak bos nya, jadi kita harus selesaikan dulu dengan bosnya maka bisa masuk ke anak jalanan. Mereka sudah seperti dijual oleh mafia atau bos bosnya..."(I4,37)

Dinas Pemuda dan Olahraga juga mengungkapkan kendala yang dihadapi dalam pelaksanaan program. Sesuai kutipan berikut ini,

“...Sementara saat ini belum dilakukan pemantauan $\mathrm{mb}$, karena belum kita anggarkan. Insyaalah rencana kedepan akan kita pantau agar mereka bekerja secara benar..." (I2,52)

Dinas Pendidikan juga mengungkapkan terkait pemantauaan yang belum dilaksanakan. Seperti kutipan berikut ini,

“...Belum mbak, belum dilakukan. Kita fokus dulu pada kurikulum dan sosialisasi karena juga semuanya masih berjalan satu tahun ini dan belum kita anggarkan juga. Pelan- pelan dulu lah mbak..." $(I 1,34)$

Berbeda dengan informasi dari BNNK Surabaya, kendala mereka yaitu kurangnya SDM. Seperti kutipan berikut, 
“...Kendala kita lebih ke interen tenaga penyuluh, PNS 2, Non PNS 4 atau 5, misalnya kegiatan MOS kita kebanjiran permintaan. Kalau untuk eksternal kebanyakan sih ke kecamatan kecamatan ya, susah mensinkronkan waktu, waktunya pas kadang tidak sesuai dengan target pesertanya, sama menyocokkan jadwal, jadi koordinasi dulu dengan kelurahan atau kecamatan... "(I5,27)

Berdasarkan ungkapan dari pemerintah dan BNNK Surabaya, mereka memiliki kendala dalam pelaksanaan program, yaitu SDM tenaga penyuluh yang terbatas, sulit menjangkau para anak jalanan, dan belum dilakukan pemantauan. Sesuai informasi Dinas Pendidikan dan Dispora, mereka belum melakukan pemantauan karena masih fokus melaksanakan kegiatan pencegahan dan belum dianggarkan. Dinas Kesehatan memiliki kesulitan dalam penjangkauan terhadap anak jalanan karena sudah dikuasai oleh para mafia yang mengakomodir mereka.

Kerjasama lintas sektoral sudah dilaksanakan oleh pemerintah dengan BNNK Surabaya, seperti yang diungkapkan Dinas Pendidikan. Berikut kutipannya,

“...Kemaren dinas pendidikan itu, bersamaBNN, ituhanyasatu-satunyadi Indonesia yang mempunyai kurikulum integrasi anti narkoba di sekolah, jadi misalnya matematika atau e pelajaran bahasa di indonesia... "'(I1,34)

Sama halnya yang diungkapkan oleh Dinas Pemuda dan Olahraga, seperti kutipan berikut ini,

“...Kita kerjasama dengan BNN ya, jadi $B N N$ sebagai narasumber ya... ”(I2,52)

Dinas Pariwisata dan Kebudayaan juga melakukan kerjasama dalam pelaksanaan program, seperti kutipan berikut ini,

“...Kegiatan sosialisasi itu bukan kita, itu lebih cenderung kerjasama dengan Dinas Kesehatan dan BNN..." $(I 3,35)$
Dinas Kesehatan juga melakukan kerjasama lintas sektoral. Seperti kutipan berikut ini,

“...Kita setiap melakukan sosialisasi selalu kerjasama dengan dinas terkait mbak ya, dan BNN. Kita fokus pada test urine nya..." (I4,37).

Responsivitas masyarakat yang mulai berjalan yaitu koselor sebaya, kader pemuda anti narkoba, para guru BK, dan orangtua. Seperti kutipan berikut ini,

“...Alasan kita terbentuknya konselor sebaya yaitu untuk bisa menjangkau lebih ke para siswa, dan mereka mampu mensosialisasikan itu, mereka sudah kita latih, karena kalau kita sendiri kesana juga tidak mampu, selain itu tadi sudah masuk dalam kurikulum belajar..." (I1,34)

Dinas Pendidikan juga mengungkapkan peran aktif guru BK. Seperti kutipan berikut ini,

“...Selain itu juga ada pelatihan kepada Guru BK agar mereka tahu arah pelaporannya kemana..." $\left(\mathrm{I}_{1}, 34\right)$

Dispora mengatakan peran kader pemuda anti narkoba, seperti kutipan berikut ini,

“...Nah kader pemuda ini, mereka nanti dilingkungan mereka sendiri kalau memang dia bisa memberikan pencerahan, sosialisasi, kalau itu dilingkungan mereka sendiri..."(I2,52)

BNNK Surabaya juga mengungkapkan peran aktif orangtua. Seperti kutipan berikut ini,

“...Kita memberikan pelatihan kepada masyarakat mbak ya, khususnya para orang tua agar mereka memiliki pemahaman untuk melindungi anaknya dari jeratan narkoba itu. Ada orang tuanya secara suka rela agar anaknya di rehab karena diketahui kalau anaknya menggunakan narkoba..." $(\mathrm{I} 5,27)$ 


\section{PEMBAHASAN}

Jika dibandingkan antara normatif dan realita, dukungan pemerintah mencapai target sasaran program pencegahan penyalahguna narkoba di kota Surabaya belum secara optimal. Penyalahgunaan narkoba meningkat dari tahun 2014 sampai 2015karena masih ada beberapa masalah dan kendala. Kendala tersebut diantaranya sulit menjangkau anak jalanan, SDM yang terbatas serta belum dilakukan pemantauan setelah program dibentuk yaitu konselor sebaya, kader pemuda anti narkoba, kurikulum integrasi anti narkoba.

Berdasarkan Undang-Undang Pendidikan PP Nomor 32 Tahun 2013 tentang Standar Nasional Pendidikan (S.N.P) terkait monitoring dan evaluasi kurikulum pendidikan dilakukan oleh pemerintah daerah ataupun kota. Secara normatif dilakukan oleh dinas pendidikan dalam pemantauan kurikulum integrasi anti narkoba. Menurut Dunn (2012) pemantauan memiliki fungsi yaitu kepatuhan, dimana pemantauan bermanfaat dalam penentuan tindakan dari para administrator program, staff, dan pelaku lain sesuai dengan prosedur yang sudah dibuat. Kepatuhan disini diartikan program pencegahan penyalahguna narkoba sudah berjalan sesuai dengan standart normatif yang ada. Setiap program jika tidak dilakukan pemantauan dan evaluasi tidak akan diketahui keberhasilannya, seperti pembentukan konselor sebaya, kader pemuda anti narkoba, dan kurikulum integrasi anti narkoba. Pemantauan memiliki peranan penting dalam keberhasilan suatu program, salah satunya program pencegahan penyalahguna narkoba. Jika pemantauan dilakukan oleh pemerintah setelah program dilaksanakan, maka akan diketahui tingkat keberhasilan pelaksanaan program. Sesuai dengan Perwali, ada ketentuan waktu dalam melaksanakan pemantauan dan evaluasi yaitu setiap satu tahun sekali.

Kendala lain yang dihadapi yaitu melakukan penjangkauan di kalangan anak jalanan, sehingga hal ini perlu dilakukan strategi yang sesuai dengan sasaran. Menurut Departemen Sosial RI (2005) terkait anak jalanan yaitu anak yang memiliki kehidupan dijalanan dan sebagian banyak menghabiskan waktu dijalanan.
Anak jalanan mencari nafkah ataupun hanya berkeliaran dijalanan sehingga dapat menjadi pemicu dalam penyalahgunaan narkoba karena faktor lingkungan dan kurangnya pengetahuan terkait narkoba berpengaruh besar terhadap penyalahgunaan narkoba. Anak jalanan memiliki hak terkait pengetahuan pemahaman narkoba. Pemberian informasi tidak hanya dilakukan kepada anak yang berada di pendidikan formal. Anak jalanan memiliki risiko tinggi terhadap penyalahgunaan narkoba karena minimnya informasi dan lingkungan yang mendukung. Faktor utama yang menyebabkan penyalahgunaan narkoba yaitu lingkungan. Jika lingkungan sekitar mendukung, maka akan mudah mereka terjebak dalam penyalahgunaan narkoba.

Masalah selanjutnya adalah tidak memiliki kesesuaian target sasaran dengan realisasi di lapangan terkait pencegahan narkoba. Pelaksanaan program menjadi komitmen bersama di semua elemen masyarakat. Menurut Kadamarta (2012) komitmen bersama memiliki pengaruh yang kuat terhadap terealisasinya program pencegahan penyalahguna narkoba. Komitmen ini dilakukan oleh masyarakat ataupun pihak pemerintah melalui penyatuan dan penyelarasan rencana aksi.

Dukungan pemerintah diantaranya sosialisasi di masyarakat, pembentukan konselor sebaya, kurikulum integrasi anti narkoba, kader pemuda anti narkoba, dan pelaksanaan TOT. Pemerintah melaksanakan program berdasarakan Perwali Surabaya Nomor 65 Tahun 2014 dan mengacu pada SK Walikota. Salah satu cara upaya pencegahan yang dilakukan pemerintah yaitu sosialisasi. Tujuan sosialisasi agar masyarakat dapat mencegah penyalahgunaan narkoba. Menurut Martono dan Joewana (2008) pendekatan sosialisasi memiliki bobot tertinggi dalam pencegahan penyalahguna narkoba terutama pada remaja. Pemerintah menganggap para remaja tidak memiliki pengetahuan tentang bahaya narkoba, sehingga perlu diberikan informasi. Realita dilapangan asumsi ini tidak benar karena masyarakat jenuh dengan penyuluhan. Pemberian informasi belum memberikan solusi dalam pencegahan penyalahgunaan narkoba. Permasalahan yang mereka hadapi 
yaitu apa yang dapat mereka lakukan dan bagaimana caranya. Martono dan Joewana (2008) juga mengatakan alasan pendekatan informatif kurang maksimal dalam mencegah penyalahguna narkoba, karena informasi yang disampaikan dengan cara menakut-nakuti dan memperlihatkan cara pemakaian secara langsung. Pesan menakutnakuti sulit diterima oleh para remaja. Mereka menganggap pemberian informasi melalui sosialisasi hanya menanamkan rasa keingintahuan yang tinggi untuk mencoba menyalahgunakan narkoba. Pemerintah memberikan informasi kepada masyarakat melalui contoh langsung cara pemakaian dan pengaruh narkoba. Pemerintah beranggapan agar dapat mencegah pemakaiannya. Akan tetapi menurut Martono dan Joewana (2008) menunjukkan hasil sebaliknya, mereka memiliki keinginan yang besar untuk mencobanya. Masyarakat khususnya para remaja mempunyai rasa ingin tahu yang tinggi, semakin mereka dilarang, maka mereka akan semakin mendekati larangan tersebut. Ketika belum memiliki dasar yang kuat untuk menghindari penyalahgunaan narkoba, mereka akan terjebak.

Alasan terbentuknya konselor sebaya yaitu sebagai penghubung pemerintah dengan masyarakat dalam penyampaian informasi terkait narkoba dan bahayanya. Konselor sebaya akan menyampaikan kepada teman sebayanya yang belum mendapatkan informasi dari pemerintah terkait narkoba tersebut. Sesuai teori Kadarmata (2012) terkait peran dinas pendidikan yaitu pemberdayaan masyarakat di lingkungan sekolah. Hal ini yang sudah terbentuk pada konselor sebaya serta fungsinya sebagai pencegahan berbasis pembinaan kecerdasan emosional karena emosi mereka yang sudah terbentuk.

Modul terkait narkoba dalam kurikulum integrasi anti narkoba masuk sistem belajar mengajar di tingkat SMP dan SMA. Menurut Ramly (2006) kurikulum diartikan sebagai output sistem perkembangan kegiatan belajar mengajar. Kurikulum integrasi anti narkoba merupakan perkembangan masalah penyalahgunaan narkoba di Surabaya, sehingga perlu dikembangkan inovasi baru dalam sistem belajar mengajar. Melalui kurikulum ini, pihak sekolah membekalkan ilmu dan pengetahuannya terkait pemahaman narkoba.

Dispora melaksanakan TOT di Pacet Mojokerto dengan tujuan untuk membentuk kader pemuda anti narkoba. Pelaksanaan TOT tersebut berdasarkan Peraturan Walikota Surabaya nomor 65 tahun 2014. Subargus (2011) mengatakan tujuan pelaksanaan training tidak hanya untuk memberikan pengetahuan saja, melainkan untuk berbuat lebih baik. Output TOT tidak hanya selesai pada pelaksanaan saja, akan tetapi mampu membentuk kader pemuda anti narkoba yang berkualitas dan memberikan kontribusi dalam hal pencegahan penyalahguna narkoba.

Pelaksanaan program pencegahan penyalahguna narkoba memiliki kaitan dengan kerjasama lintas sektoral. Government of South Australia (2010) mengungkapkan bahwa salah satu kunci mencapai HIAP adalah adanya penciptaan aliansi atau kerjasama dan kemitraan yang mengakui kepentingan bersama dan share target. Kerjasama lintas sektoral merupakan salah statregi keberhasilan HIAP. Berdasarkan SK Walikota Tentang Tim aksi P4GN, pemerintah yang bertanggung jawab dalam hal pencegahan penyalahguna narkoba melaksanakan tugasnya sesuai dengan tupoksi masing-masing dan kerjasama dengan BNN Kota Surabaya. Peran BNNK dalam melaksanakan program pencegahan sebagai fasilitator dari SKPD terkait. Kerjasama lintas sektoral sudah mulai berjalan dengan adanya perwali tersebut dan lebih terintegrasi.

Kerjasama lintas sektoral yang sudah terimplementasi diantaranya Dinas Pendidikan sebagai koordinator dalam hal program pencegahan penyalahguna narkoba bekerja sama dengan BNN kota Surabaya sebagai fasilitator. kerjasama dengan yang dilakukan Dinas Kesehatan ketika akan melakukan test urine selesai pelaksanaan sosialisasi. Selain itu ketika akan memetakan wilayah di tempat hiburan yang rentan dengan transaksi narkoba, BNN bekerjasama dengan Dinas Pariwisata Dan Kebudayaan. Dinas Pemuda dan Olahraga juga selalu bekerja sama dengan BNN kota Surabaya sebagai fasilitator dalam penyampaian informasi terkait pemahaman 
narkoba dan pembentukan kader pemuda anti narkoba.

Responsifitas masyarakat memiliki peranan penting dalam pencegahan penyalahguna narkoba. Berdasarkan hasil penelitian, masyarakat memiliki respons positif serta berpartisipasi dalam program penyalahgunaan narkoba, walaupun belum secara keseluruhan masyarakat melakukan partisipasi. Partisipasi masyarakat dalam program pencegahan tersebut yaitu terbentuknya konselor sebaya, mereka diharapkan mampu menyambungkan informasi ke masyarakat, membantu program pemerintah dalam hal pencegahan penyalahguna narkoba tersebut. selain koselor sebaya, kader pemuda anti narkoba, mereka juga sebagai penyambung informasi dari pemerintah dalam hal pencegahan penyalahguna narkoba dan juga melaporkan ketika disekitar lingkungannya ada yang menyalahgunakan narkoba tersebut.

Peran masyarakat dalam pencegahan penyalahguna narkoba di sekolah yaitu guru Bimbingan Konseling (BK). Guru BK memiliki peranan untuk memantau para siswa yang memiliki perilaku kurang baik. Selain itu, kewenangan guru BK memberikan informasi kepada para siswa agar terhindar dari penyalahgunaan narkoba. Menurut Sarwono (2010) peran guru BK memberikan bimbingan ataupun konseling secara pribadi terkait permasalahan siswa. Salah satu permasalahannya yaitu perubahan perilaku pada siswa yang tidak seperti biasanya. Berdasarkan peranan guru BK, guru BK dapat mengetahui siswa yang melakukan penyalahgunaan narkoba atau tidak. Kemudian guru BK segera melaporkan kondisi siswa ke BNNK Surabaya untuk dilakukan rehabilitasi ketika ada yang menyalahgunakan narkoba.

Orang tua memiliki peranan penting dalam hal pencegahan penyalahguna narkoba. Pemberian informasi terhadap para orang tua mampu melindungi anaknya untuk tidak menyalahgunakan narkoba. Para orang tua yang sudah diberikan pelatihan terkait pemahaman dan pencegahan narkoba diharapkan mampu menjaga anaknya untuk tidak menyalahgunakan narkoba. Selain itu orang tua juga selalu memberikan waktu sebagai pendengar yang baik bagi anak untuk mengetahui permasalahannya. Perhatian yang diberikan orang tua terhadap anaknya dapat menumbuhkan rasa tanggung jawab anak untuk memberikan yang terbaik kepada orang tua mereka.

Peran serta masyarakat sangat penting dalam hal tercapainya suatu tujuan kebijakan, peran masyarakat dikaitkan dengan Peraturan Walikota Surabaya Nomor 65 Tahun 2014. Seperti yang disampaikan oleh Dhermawan (2012) terkait masyarakat dikatakan sebagai masyarakat yang mandiri apabila mereka mampu mengenali masalah yang ada pada mereka ataupun lingkungan sekitar serta berbagai faktor yang mempengaruhi masalah tersebut.

\section{KESIMPULAN}

Perwali Surabaya Nomor 65 Tahun 2014 tentang rencana aksi kebijakan dan strategi daerah bidang P4GN memuat beberapa program dalam pencegahan penyalahguna narkoba. Program tersebut diantaranya sosialisasi, pembentukan konselor Sebaya, pembentukan kader pemuda anti narkoba, pelaksanaan TOT, dan kurikulum integrasi anti narkoba di tingkat SMP serta SMA. Pencapaian target sasaran dalam pelaksanaan program pencegahan penyalahguna narkoba di kota Surabaya belum mencapai secara keseluruhan, karena masih ada beberapa kendala yaitu sulit menjangkau kalangan anak jalanan, keterbatasan SDM pelaksana. Masalah yang dihadapi adalah belum dilakukan pemantauan karena belum dianggarkan.

Dukungan yang dilakukan oleh pemerintah dalam pencegahan penyalahguna narkoba di kota Surabaya sudah dilaksanakan sesuai dengan Perwali Surabaya Nomor 65 Tahun 2014. Bentuk dukungan pemerintah adalah sosialisasi, pembentukan konselor sebaya, kurikulum integrasi anti narkoba, pembentukan kader anti narkoba, dan pelaksanaan TOT.

Kerjasama lintas sektoral memiliki pengaruh yang kuat dalam keberhasilan suatu program, salah satunya program pencegahan penyalahguna narkoba. Berdasarkan SK Walikota, untuk memaksimalkan pelaksanaan program perlu dilakukan kerjasama lintas sektoral. Selain 
itu juga sesuai dengan salah satu strategi HIAP yaitu kerjasama lintas sektoral.

Masyarakat memiliki peran penting dalam pencegahan penyalahguna narkoba. Masyarakat sudah mulai merespon secara positif dan melakukan peran aktif dalam pencegahan penyalahguna narkoba. Terbentuknya konselor sebaya, kader pemuda anti narkoba, peran orang tua, peran guru BK sudah mulai berjalan dengan baik. Pemerintah hanya melakukan pendampingan yang inten agar peran tersebut dilaksanakan oleh masyarakat secara keseluruhan.

\section{DAFTAR PUSTAKA}

Akhri, S. 2012.Kejahatan Narkotik dan Psiotropik. Jakarta: Gramata Publising.

Bakhri, S. 2012. Kejahatan Narkotik dan Psiotropik. Jakarta: Gramata Publising.

BNN. 2009.Advokasi Pencegahan Penyalahgunaan Narkoba. Jakarta Timur: BNN.

BNN. 2011.Pedoman Prosedur Kerja Bidang Advokasi P4GN. Jakarta Timur.

Damanik, K.I. 2012. Otonomi Daerah, Etnonasionalisme, Dan Masa Depan Indonesia. Jakarta: YOI.

Depdiknas, S.n.2.t..s.i.t.p.d.p.i..m. 2006Permendiknas. Jakarta: PAUPPAI.

Depkes, R. 2009.Profil Kesehatan Indonesia. Jakarta: Departemen Republik Indonesia.

Domai, D. 2011.Sount Governance. Malang: UB Press.

Duun, W.N. 2012. Pengantar Analisis Kebijakan Publik. Yogyakarta: Gajah Mada University Press.

Green, T.D.\&.B.A. 2012.Multimedia Project In The Classroom. USA: Corwin Press, Inc.

Ramly, Ishak. 2006. Inilah Kurikulum Sekolah. Jakarta: PTS Profesional.

Juliana, L.F.-N.S. 2013. Narkoba, psikotropika dan gangguan jiwa, Yogyakarta: Nuha Medika.
Kadarmanta. 2012. Mencegah Narkoba Di Sekolah, Jakarta: Forum media utama.

Kemenkes RI. 2011. Promosi Kesehatan Didaerah Bermasalah Kesehatan.

Kemenkes RI. 2014. Infodatin Sayno to Drugs say yes to LiveI. Jakarta: Kementerian Kesehatan Republik Indonesia.

Lisa FR-Nengah Sutrisna, J. (2013) Narkoba, psikotropika dan gangguan jiwa, Yogyakarta: Nuha Medika.

Martono, lydia Harlina dan Joewana, Satya. 2008. Peran orangtua dalam mencegah dan menanggulangi Penyalahgunaan Narkoba. Jakarta: Balai Pustaka. Maulana, H.D.J. 2009.Promosi Kesehatan, Jakarta: EGC.

Notoatmodjo, S. 2005.Promosi Kesehatan Teori Dan Aplikasi, Jakarta: Rienika Cipta.

Notoatmodjo, S. 2012.Promosi Kesehatan Dan Perilaku Kesehatan. Jakarta: Rineka cipta.

Perwali Surabaya, n.6. 2014. Kebijakan pencegahan pemberantasan penyalahgunaan peredaran gelap narkoba.

Pina, N. 2016. Peran Pemerintah Kota Surabaya dalam pencegahan narkoba. Skripsi. Fakultas Kesehatan Masyarakat Universitas Airlanga. Surabaya.

Pratiwi.Niniek, L. 2013.Pemberdayaan Masyarakat Dan Perilaku Kesehatan, Surabaya: AUP.

Salam, A. 2007.Desentralisasi dan Otonomi Daerah, Jakara: LIPI Press.

Subargus, Amin. 2011. Promosi Kesehatan Melalui Pendidikan Kesehatan Masyarakat. Yogyakarta: Gyoshin Publishing.

Sugiyono. 2014. Memahami Penelitian Kualitatif, Bandung: CV. Alfabeta.

UPI, F. 2007.Ilmu dan Aplikasi Pendidikan. PT.Imtima. 